\title{
Psychologiczne uwarunkowania preferencji w zakresie ksztaltu systemu politycznego w Polsce na podstawie badań empirycznych
}

\begin{abstract}
A naliza preferencji w zakresie kształtu systemu politycznego w Polsce jest ważna z punktu widzenia jego akceptacji przez obywateli. W systemie demokratycznym problematyka ta nabiera szczególnego znaczenia, czego wyrazem jest wielokrotne czynienie jej przedmiotem debaty publicznej oraz badań opinii społecznej.

Przeprowadzone badania są wyrazem poszukiwań mechanizmów mających znaczenie przy formowaniu się opinii i stanowisk, dotyczących wybranych elementów systemu politycznego. Miały na celu diagnozę preferencji w zakresie systemu rządów, systemu partyjnego i jednomandatowych okręgów wyborczych w Polsce oraz zarysowanie psychologicznych różnic w grupach mających odmienne zdanie w analizowanych kwestiach. Rozpoznanie kierunku oraz istotności różnic w charakterystykach psychologicznych pozwoli na oszacowanie wartości badania uwarunkowań psychologicznych w analizie formowania się preferencji w zakresie kształtu systemu politycznego, co umożliwi zarysowanie dalszych eksploracji. Ponadto uzyskane wyniki są interesujące z poznawczego punktu widzenia - diagnozy różnic w profilach psychologicznych jednostek opowiadających się za odmiennym kształtem systemu rządów, formatem systemu partyjnego i okręgów wyborczych w Polsce.

Analiza aprobaty obywateli dla poszczególnej struktury władzy w państwie jest istotna w kontekście aktywności politycznej oraz nastrojów społecznych. Podział kompetencji między prezydentem i rządem wielokrotnie był przedmiotem sporów i dyskusji publicznych. Nie bez znaczenia jest mało precyzyjny konstytucyjny rozdział uprawnień. Harmonijne współdziałanie utrudnia również sytuacja koabitacji, w której prezydent i rząd wywodzą się z innych opcji politycznych. Ponad połowa Polaków (58\%) uważa, że niezbędne są konstytucyjne zmiany w zakresie podziału
\end{abstract}


uprawnień między prezydentem a rządem ${ }^{1}$. Ich zwolennicy przeważają wśród sympatyków każdej z cieszących się obecnie największym poparciem społecznym partii politycznych.

Wiele definicji partii politycznych akcentuje ich rolę jako łącznika między rządem a społeczeństwem. Sigmund Neumanna podkreśla, że „[...] to ważny pośrednik łączący siły społeczne i ideologie z oficjalnymi instytucjami rządowymi i wiążący je z działaniem politycznym w ramach szerszej wspólnoty politycznej"2. Z kolei Kay Lawson zwraca uwagę, że partia to organizacja zrzeszająca jednostki, która poszukuje wyborczego i pozawyborczego wsparcia ze strony społeczeństwa (lub jego części) dla określonych jej przedstawicieli po to, by mogli sprawować władzę polityczną, związaną z konkretnymi stanowiskami rządowymi, twierdząc, że władza ta wykonywana jest dla społecznego dobra ${ }^{3}$. Definicje te ściśle wiążą partie polityczne z procesami zachodzącymi w społeczeństwie, akcentują wyrażanie i agregację interesów oraz postaw, ekspresję wartości, które składają się na tożsamość wyborczą ${ }^{4}$. Partie są nośnikiem tego, co jest ważne dla danej grupy społecznej i sprawia, że jednostki ją popierają. Według badań CBOS ponad połowa Polaków uważa, że partie polityczne są niezbędne dla sprawnego działania państwa (52\%), odmiennego zdania jest co piąty badany (18\%). W ostatnim dziesięcioleciu sądy te były w miarę stabilne ${ }^{5}$. Tym samym szczególnego znaczenia nabiera analiza preferencji obywateli w zakresie kształtu sceny partyjnej w Polsce.

Działacze Platformy Obywatelskiej od kilku lat postulują zmiany w systemie politycznym kraju, w tym zdecydowanie popierają wprowadzenie jednomandatowych okręgów wyborczych w wyborach parlamentarnych, równocześnie zmieniając system głosowania z proporcjonalnego na większościowy. Kwestia ta wielokrotnie miała swoje miejsce w debacie publicznej. Według badań CBOS w Polsce w ostatnich latach utrzymuje się systematyczny, chociaż niewielki wzrost, poparcia dla jednomandato-

1 Podzial kompetencji między Prezydentem a Premierem, Centrum Badania Opinii Społecznej, Komunikat z badań nr BS/154/2008, Warszawa, kwiecień 2008.

${ }_{2}$ Modern political parties, red. S. Neumann, Chicago 1958, s. 396.

3 K. Sobolewska-Myślik, Partie i systemy partyjne na świecie, Warszawa 2004, S. 8 .

4 Leksykon politologii, red. R. Herbut, A. Antoszewski, Wrocław 1999, s. 386.

5 Dwadzieścia lat przemian ustrojowych w Polsce, „Opinie i Diagnozy”, Centrum Badania Opinii Społecznej, Warszawa 2009, s. 104-106. 
wych okręgów wyborczych. W 2008 roku ordynację większościową popierało 40 procent respondentów ${ }^{6}$.

Przedmiotem analizy uczyniono następujące zmienne psychologiczne: samoocenę, dyspozycyjny optymizm, poczucie własnej skuteczności oraz dyspozycyjny lęk. Na podstawie założeń teoretycznych można przypuszczać, że pełnią one istotną rolę w kształtowaniu preferencji jednostek dotyczących kształtu systemu politycznego.

Samoocena. Samoocena rozumiana jest najczęściej jako uogólniona świadoma postawa wobec JA. Morris Rosenberg, autor wykorzystanego w pomiarze narzędzia, podkreśla, iż wysoka samoocena oznacza przekonanie, że jest się wystarczająco dobrym, wartościowym człowiekiem, co nie musi świadczyć o tym, że dana osoba, prezentująca wysoki poziom samooceny uważa siebie za lepszą od innych. Niska samoocena oznacza niezadowolenie $\mathrm{z}$ siebie, odrzucenie własnego $\mathrm{JA}^{7}$. Tak rozumiana samoocena jest traktowana jako cecha względnie stała. Jej poziom diagnozowany był za pomoca Skali Samooceny SES.

Dyspozycyjny optymizm. Przez dyspozycyjny optymizm rozumiemy sposób postrzegania świata, polegający na spodziewaniu się większej ilości pozytywnych doświadczeń. Michael F. Scheier i Charles S. Carver, autorzy koncepcji, uznają go raczej za stałą cechę osobowości niż zmienną zależną od bieżącej sytuacji. Optymizm wzbudza w jednostkach motywację, wytrwałość, zaangażowanie w dążeniu do wyznaczonych celów ${ }^{8}$. Dyspozycyjny optymizm mierzono za pomocą Testu Orientacji Życiowej LOT-R autorstwa Michaela F. Scheiera, Charlesa S. Carvera, Michaela W. Bridgesa w polskiej adaptacji Ryszarda Poprawy i Zygfryda Juczyńskiego.

Poczucie własnej skuteczności. Zmienna ta określa „siłę ogólnego przekonania jednostki co do skuteczności radzenia sobie $z$ trudnymi sytuacjami i z przeszkodami"'. Poczucie to mierzono za pomocą Skali Uogólnionej Własnej Skuteczności (GSES) autorstwa Ralfa Schwarzera, Michaela Je-

${ }^{6}$ Polacy o proponowanych zmianach $w$ systemie politycznym, Centrum Badania Opinii Społecznej, Komunikat z badań nr BS/56/2008, Warszawa, kwiecień 2008.

7 M. Laguna, K. Lachowicz-Tabaczek, I. Dzwonkowska, Skala Samooceny SES Morrisa Rosenberga - polska adaptacja metody, „Psychologia Społeczna” 2007, t. 2, nr 2(4), s. 164.

${ }^{8}$ M. F. Scheier, C. S. Carver, Optimism, coping, and health: assessment and implications of generalized outcome expectancies, „Health Psychology” 1985, nr 4, s. 219-247.

9 Z. Juczyński, Narzędzia pomiaru w promocji i psychologii zdrowia, Warszawa 2001, s. 97. 
rusalema i Zygfryda Juczyńskiego. Autorzy odwołują się do koncepcji oczekiwań i pojęcia własnej skuteczności Alberta Bandury. Oczekiwanie własnej skuteczności ma związek z kontrolą swoich działań i może dotyczyć określonych obszarów życia jednostki, jak i stanowić ogólne przekonanie, dotyczące sytuacji nowych czy trudnych.

Lęk jako cecha. Cecha lęku rozumiana jest jako ,motyw lub dyspozycja behawioralna, która czyni jednostkę podatną na postrzeganie szerokiego zakresu obiektywnie niegroźnych sytuacji jako zagrażających i reagowanie na nie stanami lęku, nieproporcjonalnie silnym w stosunku do wielkości obiektywnego niebezpieczeństwa"10. W definicji tej szczególną rolę przypisuje się procesom poznawczym, które w sytuacji lękowej odgrywają znaczącą rolę. W tym obszarze można mówić o pewnej stabilności lękowego reagowania. Cechę lęku mierzono za pomocą Inwentarza Stanu i Cechy Lęku (arkusz X-2). Jest to adaptacja amerykańskiego testu State Trait Anxiety Inventory (STAI) opracowanego przez Charlesa D. Spielbergera, Richarda L. Gorsucha i Roberta E. Lushene'a.

W toku badań okazało się, że wskazane charakterystyki psychologiczne nie są niezależne, korelacje między zmiennymi są dość wysokie (Tabela 1). Najsilniejsze współzależności zdiagnozowano między poziomem samooceny a dyspozycyjnym lękiem $(\mathrm{r}=-0,63)$ i optymizmem $(\mathrm{r}=0,62)$, nieco mniejsze między poziomem samoskuteczności a dyspozycyjnym lękiem $(\mathrm{r}=-0,59)$, pozostałe zmienne wykazują współzależność na poziomie 0,57 , przy czym jest to korelacja dodatnia w przypadku samoskuteczności a poziomami dyspozycyjnego optymizmu i samooceny oraz ujemna w odniesieniu do dyspozycyjnego lęku i optymizmu. Wyniki te korespondują z innymi badaniami prezentowanymi w literaturze przedmiotu ${ }^{11}$.

10 T. Sosnowski, K. Wrześniewski, Polska adaptacja inwentarza STAI do badania stanu $i$ cechy lęku, „Przegląd Psychologiczny” 1983, nr 26(2), s. 395.

11 Z. Juczyński, Narzędzia pomiaru..., op. cit.; M. F. Scheier, C. S. Carver, M. W. Bridges, Distinguishing optimism from neuroticism (and trait anxiety, self-mastery, and self-esteem): A reevaluation of the Life Orientation Test, „Journal of Personality and Social Psychology" 1994, nr 67, s. 1063-1078; B. Prażmowska, G. Puto, E. Kowal, B. Gierat, Niespetnione macierzyństwo, http://www.termedia.pl/magazine.php?magazine_id=5\&article_id=13877\&magazine_subpage $=$ FULL_TEXT, 23.05.2010; A. Turska-Kawa, Psychologiczne portrety elektoratów $w$ wyborach do Parlamentu Europejskiego w 2009 roku, w: Wybory do Parlamentu Europejskiego w Polsce 2009, red. R. Glajcar, W. Wojtasik, Katowice 2010, s. 97-118. 
Interkorelacje pomiędzy wybranymi zmiennymi psychologicznymi

\begin{tabular}{|l|c|c|c|c||}
\hline & Samoocena & $\begin{array}{c}\text { Dyspozycyjny } \\
\text { optymizm }\end{array}$ & $\begin{array}{c}\text { Samoskutecz- } \\
\text { ność }\end{array}$ & $\begin{array}{c}\text { Dyspozycyjny } \\
\text { lęk }\end{array}$ \\
\hline Samoocena & 1 & $0,62^{* *}$ & $0,57^{* *}$ & $-0,63^{* *}$ \\
\hline Dyspozycyjny optymizm & $0,62^{* *}$ & 1 & $0,57^{* *}$ & $-0,57^{* *}$ \\
\hline Samoskuteczność & $0,57^{* *}$ & $0,57^{* *}$ & 1 & $-0,59^{* *}$ \\
\hline Dyspozycyjny lęk & $-0,63^{* *}$ & $-0,57^{* *}$ & $-0,59$ & 1 \\
\hline
\end{tabular}

*** Korelacja jest istotna na poziomie 0,01 (dwustronnie).

Prezentowane badania są częścią ogólnopolskiego interdyscyplinarnego projektu, który został zrealizowany w okresie listopad-grudzień 2009 roku na ogólnokrajowej reprezentatywnej próbie dorosłych Polaków, dobranej w sposób kwotowo-warstwowy $(\mathrm{N}=1086)^{12}$. Populacja została podzielona w sposób kompletny i rozłączny na warstwy, które stanowią województwa. Procedurą doboru kwotowego objęto następujące zmienne: miejsce zamieszkania (miasto-wieś), płeć i wiek.

\section{System rządów}

Badani proszeni byli o opowiedzenie się za jednym $\mathrm{z}$ dwóch systemów rządów: prezydenckim lub parlamentarno-gabinetowym. Każda z tych opcji była w kwestionariuszu doprecyzowana definicyjnie (odpowiednio: ,jednoosobowa władza wybierana przez obywateli w powszechnych wyborach” oraz ,władza w rękach premiera wybieranego przez Parlament”). Kafeteria uwzględniała również odpowiedź „nie mam zdania”.

Wśród badanych blisko połowa to zwolennicy systemu parlamentarno-gabinetowego, który zakłada szczególny stosunek względem siebie trzech naczelnych organów państwa - prezydenta, parlamentu i rządu. System ten uprzywilejowaną pozycję w układzie władzy przypisuje parlamentowi, a podstawowe kompetencje egzekutywy sprawuje rząd. Uprawnienia prezydenta są w nim bardzo ograniczone. Co czwarty badany opowiedział się za systemem prezydenckim, który cechuje silna, spersonalizowana egzekutywa będąca wynikiem legitymizacji wyborczej, po-

12 Interdyscyplinarny Zespół Badawczy, Badania Elektoratu 2009, http://www.badaniaelektoratu2009.us.edu.pl/. 
chodzącej z wyborów powszechnych. W systemie tym mocna pozycja prezydenta podkreślana jest przez wysoki poziom jego niezależności od innych instytucji oraz szereg uprawnień w zakresie administracyjnym, polityki zagranicznej, obronności itp. Niespełna jedna trzecia próby nie miała zdania w tej kwestii (Tabela 2).

Tabela 2

Charakterystyki psychologiczne osób o odmiennych preferencjach systemu rządów

\begin{tabular}{|c|c|c|c|c|c|c|c|c|c|}
\hline & \multirow{2}{*}{$\mathbf{N}$} & \multicolumn{2}{|c|}{ Samoocena } & \multicolumn{2}{|c|}{$\begin{array}{c}\text { Dyspozycyjny } \\
\text { optymizm }\end{array}$} & \multicolumn{2}{|c|}{$\begin{array}{c}\text { Samosku- } \\
\text { teczność }\end{array}$} & \multicolumn{2}{|c|}{$\begin{array}{l}\text { Dyspozy- } \\
\text { cyjny lęk }\end{array}$} \\
\hline & & \begin{tabular}{|l} 
średni \\
wynik
\end{tabular} & $\%^{a}$ & $\begin{array}{l}\text { średni } \\
\text { wynik }\end{array}$ & $\%$ & \begin{tabular}{|l|} 
średni \\
wynik
\end{tabular} & $\%$ & $\begin{array}{l}\text { średni } \\
\text { wynik }\end{array}$ & $\%$ \\
\hline $\begin{array}{l}\text { Zwolennicy systemu } \\
\text { prezydenckiego }\end{array}$ & 281 & 38,8 & 77,6 & 20,9 & 69,7 & 29,3 & 73,2 & 48,6 & 60,7 \\
\hline $\begin{array}{l}\text { Zwolennicy systemu } \\
\text { parlamentarno-gabine- } \\
\text { towego }\end{array}$ & 476 & 39,0 & 78,0 & 21,6 & 72,0 & 29,6 & 74,0 & 47,6 & 59,5 \\
\hline Nie mam zdania & 329 & 36,6 & 73,2 & 20,9 & 69,7 & 27,7 & 69,2 & 50,6 & 63,2 \\
\hline
\end{tabular}

${ }^{a}$ Procent stanowi przeliczenie średniego wyniku w odniesieniu do maksymalnej ilości punktów możliwych do zdobycia w danej skali. Zabieg ten umożliwił porównanie między sobą wyników różnych skal.

Źródło: Opracowanie własne.

Zwolennicy systemu prezydenckiego w porównaniu z jednostkami preferującymi system parlamentarno-gabinetowy prezentują nieco niższy poziom samooceny, dyspozycyjnego optymizmu, poczucia własnej skuteczności oraz wyższy poziom lęku jako cechy, jednak różnice istotne statystycznie odnotowano jedynie w przypadku dyspozycyjnego optymizmu (Tabela 3). Optymizm to ważna dyspozycja odpowiedzialna za motywację i zaangażowanie w podjęte działania. Optymizm, traktowany jako dyspozycja w kategoriach zgeneralizowanych oczekiwań pozytywnego wyniku swoich działań czy zdarzeń, może współdecydować o sposobie, w jaki jednostka reaguje na wymagania otoczenia. „Optymistyczny styl wyjaśniania kładzie kres bezradności, natomiast pesymistyczny jeszcze ją pogłębia. Sposób, w jaki wyjaśniamy sobie różne wydarzenia, określa nasze do nich podejście i sprawia, że stajemy się bezradni, albo że, traktując spotykające nas niepowodzenia jako chwilowe, mobilizujemy się do większej aktywności”,13.

13 M. Seligmann, Optymizmu można się nauczyć, Poznań 1995, s. 32. 
Istotność różnic w zakresie analizowanych zmiennych psychologicznych między grupami o różnych preferencjach w zakresie preferencji systemu rządów w Polsce

\begin{tabular}{|c|c|c|c|c|}
\hline Zmienna & & $\mathbf{t}$ & $d f$ & $\mathbf{p}$ \\
\hline \multirow[t]{6}{*}{ Samoocena } & Zwolennicy systemu prezydenckiego & \multirow[t]{2}{*}{$-0,241$} & \multirow[t]{2}{*}{747} & \multirow[t]{2}{*}{ n.i. } \\
\hline & Zwolennicy systemu parlamentarno-gabinetowego & & & \\
\hline & Zwolennicy systemu prezydenckiego & \multirow[t]{2}{*}{4,755} & \multirow[t]{2}{*}{604} & \multirow[t]{2}{*}{$\mathbf{0 , 0 0 0}$} \\
\hline & Nie mam zdania & & & \\
\hline & Zwolennicy systemu parlamentarno-gabinetowego & \multirow[t]{2}{*}{5,676} & \multirow[t]{2}{*}{795} & \multirow[t]{2}{*}{0,000} \\
\hline & Nie mam zdania & & & \\
\hline \multirow{6}{*}{$\begin{array}{l}\text { Dyspozycyjny } \\
\text { optymizm }\end{array}$} & Zwolennicy systemu prezydenckiego & \multirow[t]{2}{*}{$-2,434$} & \multirow[t]{2}{*}{747} & \multirow[t]{2}{*}{0,015} \\
\hline & Zwolennicy systemu parlamentarno-gabinetowego & & & \\
\hline & Zwolennicy systemu prezydenckiego & \multirow[t]{2}{*}{0,517} & \multirow[t]{2}{*}{604} & \multirow[t]{2}{*}{ n.i. } \\
\hline & Nie mam zdania & & & \\
\hline & Zwolennicy systemu parlamentarno-gabinetowego & \multirow[t]{2}{*}{3,069} & \multirow[t]{2}{*}{795} & \multirow[t]{2}{*}{$\mathbf{0 , 0 0 2}$} \\
\hline & Nie mam zdania & & & \\
\hline \multirow{6}{*}{$\begin{array}{l}\text { Samoskutecz- } \\
\text { ność }\end{array}$} & Zwolennicy systemu prezydenckiego & \multirow[t]{2}{*}{$-0,613$} & \multirow[t]{2}{*}{747} & \multirow[t]{2}{*}{ n.i. } \\
\hline & Zwolennicy systemu parlamentarno-gabinetowego & & & \\
\hline & Zwolennicy systemu prezydenckiego & \multirow[t]{2}{*}{3,711} & \multirow[t]{2}{*}{604} & \multirow[t]{2}{*}{$\mathbf{0 , 0 0 0}$} \\
\hline & Nie mam zdania & & & \\
\hline & Zwolennicy systemu parlamentarno-gabinetowego & \multirow[t]{2}{*}{4,782} & \multirow[t]{2}{*}{795} & \multirow[t]{2}{*}{$\mathbf{0 , 0 0 0}$} \\
\hline & Nie mam zdania & & & \\
\hline \multirow{6}{*}{$\begin{array}{l}\text { Dyspozycyjny } \\
\text { lęk }\end{array}$} & Zwolennicy systemu prezydenckiego & \multirow[t]{2}{*}{1,421} & \multirow[t]{2}{*}{747} & \multirow[t]{2}{*}{ n.i. } \\
\hline & Zwolennicy systemu parlamentarno-gabinetowego & & & \\
\hline & Zwolennicy systemu prezydenckiego & $-3,064$ & 604 & 0,002 \\
\hline & Nie mam zdania & & & \\
\hline & Zwolennicy systemu parlamentarno-gabinetowego & $-5,016$ & 795 & 0,000 \\
\hline & Nie mam zdania & & & \\
\hline
\end{tabular}

Źródło: Opracowanie własne.

Istotnie różnią się natomiast grupy osób, które opowiedziały się za określoną opcją od tych, które nie mają zdania w kwestii systemu rządów w Polsce. Jednostki nieposiadające opinii mają dużo niższy poziom samooceny, dyspozycyjnego optymizmu, samoskuteczności i wyższy poziom lęku jako cechy. Jedynie wynik dyspozycyjnego optymizmu istotnie nie wyróżnia ich od jednostek preferujących system prezydencki. Są to zatem osoby mające mniej pozytywny stosunek do JA. W badaniach Jim Blascovich i Joe Tomaka niższy poziom samooceny współwystępuje z de- 
presją oraz anomią ${ }^{14}$. Osoby te mają też większą tendencję do reagowania lękiem w różnych sytuacjach życiowych, nawet, gdy obiektywnie nie są one zagrażające. Niższy poziom własnej skuteczności nie sprzyja przezwyciężaniu tych stanów, bowiem jest to zmienna odpowiedzialna za motywację i zadaniowe reagowanie. „Ludzie, którzy nie wierzą w swoje umiejętności radzenia sobie z trudnymi zadaniami, biorą taki punkt wyjścia za sposób życia. [...] rozpamiętują swoje osobiste braki i niepowodzenia, narzekają na zły los [...] szybko się poddają. Ponieważ mają słabą wiarę we własne zdolności, wystarczy mała dawka niepowodzenia, by stracili ją do końca"15.

\section{System partyjny}

Respondenci proszeni byli o opowiedzenie się za jednym z trzech modeli koegzystencji partii politycznych w Polsce: jednopartyjnym, dwupartyjnym oraz wielopartyjnym. Z powodów eksploracyjnych, mimo braku zgodności między specjalistami co do istnienia systemu, w którym funkcjonuje tylko jedna partia, umieściliśmy tę kategorię ${ }^{16}$. Kafeteria uwzględniała również opcję „nie mam zdania”.

Wśród badanych blisko połowa to zwolennicy systemu wielopartyjnego, najczęściej występującego w państwach demokratycznych, w którym trzy lub więcej partii mają zdolność do formowania rządu. Co czwarty badany opowiedział się za systemem dwupartyjnym, charakteryzującym się tym, że dwie partie są zdolne do konkurowania o absolutną większość mandatów w parlamencie. Identyczna ilość osób nie miała zdania w analizowanej kwestii. Poniżej 10 procent respondentów wskazało jako preferowany system jednopartyjny (Tabela 4).

Podobnie jak w analizie odpowiedzi dotyczących systemu rządów zdecydowanie wyróżniają się jednostki niemające zdania w zakresie preferencji systemu partyjnego od osób, które prezentują własne zdanie. Jednostki te charakteryzuje najniższy poziom samooceny, dyspozycyjnego

14 J. Blascovich, J. Tomaka, Measures of self-esteem, w: Measures of personality and social psychological attitudes, Vol. 1: Measures of social psychological attitudes, red. J. P. Robinson, P. R. Shaver, L. S. Wrightsman, Nowy Jork 1991, s. 115-160.

15 A. Bańka, Poczucie samoskuteczności. Konstrukcja i struktura czynnikowa Skali Poczucia Samoskuteczności w Karierze Międzynarodowej, Poznań-Warszawa 2005, s. 10.

16 K. Sobolewska-Myślik, Partie i systemy..., op. cit., s. 105-107. 
optymizmu, samoskuteczności oraz najwyższy lęku jako cechy. Jednocześnie w zakresie wszystkich, poza poczuciem własnej skuteczności ${ }^{17}$, analizowanych zmiennych, bliżsi są im zwolennicy systemu jednopartyjnego (brak różnic statystycznych w tych grupach). Pośród jednostek preferujących określone systemy największe różnice zaobserwowano między zwolennikami systemu jednopartyjnego i wielopartyjnego. U sympatyków systemu wielopartyjnego zdiagnozowano istotnie wyższy poziom samooceny, dyspozycyjnego optymizmu oraz niższy lęku jako cechy. Zwolennicy systemu dwupartyjnego oscylują pomiędzy tymi grupami, zaznaczając jedynie wyraźną różnicę w wyższym poziomie samooceny w porównaniu ze zwolennikami systemu jednopartyjnego. Poczucie samoskuteczności istotnie różnicuje wyłącznie zwolenników poszczególnych opcji oraz jednostki niemające zdecydowanego zdania (Tabele 4 i 5).

Tabela 4

Charakterystyki psychologiczne osób o odmiennych preferencjach systemu partyjnego

\begin{tabular}{||l|c|c|c|c|c|c|c|c|c||}
\hline & & \multicolumn{2}{|c|}{ Samoocena } & \multicolumn{2}{|c|}{$\begin{array}{c}\text { Dyspozycyjny } \\
\text { optymizm }\end{array}$} & \multicolumn{2}{|c|}{$\begin{array}{c}\text { Samosku- } \\
\text { teczność }\end{array}$} & \multicolumn{2}{|c|}{$\begin{array}{c}\text { Dyspozycyjny } \\
\text { lęk }\end{array}$} \\
\cline { 2 - 11 } & $N$ & $\begin{array}{c}\text { średni } \\
\text { wynik }\end{array}$ & $\%$ & $\begin{array}{c}\text { średni } \\
\text { wynik }\end{array}$ & $\%$ & $\begin{array}{c}\text { średni } \\
\text { wynik }\end{array}$ & $\%$ & $\begin{array}{c}\text { średni } \\
\text { wynik }\end{array}$ & $\%$ \\
\hline $\begin{array}{l}\text { Zwolennicy systemu } \\
\text { jednopartyjnego }\end{array}$ & 88 & 37,1 & 74,2 & 20,8 & 69,3 & 29,5 & 73,7 & 50,4 & 63,0 \\
\hline $\begin{array}{l}\text { Zwolennicy systemu } \\
\text { dwupartyjnego }\end{array}$ & 269 & 38,5 & 77,0 & 21,2 & 70,7 & 29,8 & 74,5 & 48,4 & 60,5 \\
\hline $\begin{array}{l}\text { Zwolennicy systemu } \\
\text { wielopartyjnego }\end{array}$ & 460 & 39,2 & 78,4 & 21,7 & 72,3 & 30,0 & 75,0 & 47,4 & 59,2 \\
\hline Nie mam zdania & 269 & 36,6 & 73,2 & 20,3 & 67,7 & 27,3 & 68,2 & 50,8 & 63,5 \\
\hline \hline
\end{tabular}

Źródlo: Opracowanie własne.

Osoby preferujące system wielopartyjny mają w większej mierze niż jednostki opowiadające się za systemem jednopartyjnym pozytywną postawę wobec JA. W badaniach wyższy poziom samooceny współwystępuje z wyższym poziomem wytrwałości i aktywności społecznej ${ }^{18}$. Są to

17 Wśród zwolenników poszczególnych opcji systemu partyjnego osoby preferujące system jednopartyjny prezentują najniższy poziom własnej skuteczności, jednak istotnie wyższy niż jednostki nie mające zdania w tej kwestii.

18 R. F. Baumeister, L. Smart, J. M. Boden, Relation of threatened egotism to violence and aggression: The dark side of self-esteem, „Psychological Review” 1996, nr 103, s. 5-33. 
także w większej mierze optymiści, którzy stosują skuteczniejsze strategie radzenia sobie w sytuacjach trudnych. Wysoki poziom optymizmu wiąże się często z radzeniem sobie ukierunkowanym bardziej na problem niż zaprzeczanie, odwracanie uwagi czy zaprzestawanie działan ${ }^{19}$. Sprawniejsze reagowanie w konfrontacji z sytuacjami niejasnymi, nowymi, trudnymi warunkuje także niższy poziom dyspozycyjnego lęku, który może pomniejszać przeżywanie stanów lękowych w przypadku zagrożenia.

Tabela 5

Istotność różnic w zakresie analizowanych zmiennych psychologicznych między grupami o różnych preferencjach w zakresie preferencji systemu partyjnego w Polsce

\begin{tabular}{|c|c|c|c|c|}
\hline Zmienna & & t & $d f$ & $\mathbf{p}$ \\
\hline 1 & 2 & 3 & 4 & 5 \\
\hline \multirow[t]{12}{*}{ Samoocena } & Zwolennicy systemu jednopartyjnego & \multirow[t]{2}{*}{$-1,983$} & \multirow[t]{2}{*}{352} & \multirow[t]{2}{*}{0,048} \\
\hline & Zwolennicy systemu dwupartyjnego & & & \\
\hline & Zwolennicy systemu jednopartyjnego & \multirow[t]{2}{*}{$-2,981$} & \multirow[t]{2}{*}{540} & \multirow[t]{2}{*}{0,003} \\
\hline & Zwolennicy systemu wielopartyjnego & & & \\
\hline & Zwolennicy systemu jednopartyjnego & \multirow[t]{2}{*}{0,667} & \multirow[t]{2}{*}{352} & \multirow[t]{2}{*}{ n.i. } \\
\hline & Nie mam zdania & & & \\
\hline & Zwolennicy systemu dwupartyjnego & \multirow[t]{2}{*}{$-1,316$} & \multirow[t]{2}{*}{720} & \multirow[t]{2}{*}{ n.i. } \\
\hline & Zwolennicy systemu wielopartyjnego & & & \\
\hline & Zwolennicy systemu dwupartyjnego & \multirow[t]{2}{*}{3,645} & \multirow[t]{2}{*}{532} & \multirow[t]{2}{*}{$\mathbf{0 , 0 0 0}$} \\
\hline & Nie mam zdania & & & \\
\hline & Zwolennicy systemu wielopartyjnego & \multirow[t]{2}{*}{5,443} & \multirow[t]{2}{*}{720} & \multirow[t]{2}{*}{$\mathbf{0 , 0 0 0}$} \\
\hline & Nie mam zdania & & & \\
\hline \multirow{12}{*}{$\begin{array}{l}\text { Dyspozycyjny } \\
\text { optymizm }\end{array}$} & Zwolennicy systemu jednopartyjnego & \multirow[t]{2}{*}{$-0,647$} & \multirow[t]{2}{*}{352} & \multirow[t]{2}{*}{ n.i. } \\
\hline & Zwolennicy systemu dwupartyjnego & & & \\
\hline & Zwolennicy systemu jednopartyjnego & \multirow[t]{2}{*}{$-2,010$} & \multirow[t]{2}{*}{540} & \multirow[t]{2}{*}{0,045} \\
\hline & Zwolennicy systemu wielopartyjnego & & & \\
\hline & Zwolennicy systemu jednopartyjnego & \multirow[t]{2}{*}{1,133} & \multirow[t]{2}{*}{352} & \multirow[t]{2}{*}{ n.i. } \\
\hline & Nie mam zdania & & & \\
\hline & Zwolennicy systemu dwupartyjnego & \multirow[t]{2}{*}{$-1,906$} & \multirow[t]{2}{*}{720} & \multirow[t]{2}{*}{ n.i. } \\
\hline & Zwolennicy systemu wielopartyjnego & & & \\
\hline & Zwolennicy systemu dwupartyjnego & \multirow[t]{2}{*}{2,452} & \multirow[t]{2}{*}{532} & 0,015 \\
\hline & Nie mam zdania & & & \\
\hline & Zwolennicy systemu wielopartyjnego & 4,799 & 720 & 0,000 \\
\hline & Nie mam zdania & & & \\
\hline
\end{tabular}

19 M. F. Scheier, C. S. Carver, M. W. Bridges, Distinguishing optimism..., op. cit., s. $1063-1078$. 


\begin{tabular}{|c|c|c|c|c|}
\hline 1 & 2 & 3 & 4 & 5 \\
\hline \multirow[t]{12}{*}{ Samoskuteczność } & Zwolennicy systemu jednopartyjnego & \multirow[t]{2}{*}{$-0,547$} & \multirow[t]{2}{*}{352} & \multirow[t]{2}{*}{ n.i. } \\
\hline & Zwolennicy systemu dwupartyjnego & & & \\
\hline & Zwolennicy systemu jednopartyjnego & \multirow[t]{2}{*}{0,285} & \multirow[t]{2}{*}{540} & \multirow[t]{2}{*}{ n.i. } \\
\hline & Zwolennicy systemu wielopartyjnego & & & \\
\hline & Zwolennicy systemu jednopartyjnego & \multirow[t]{2}{*}{3,101} & \multirow[t]{2}{*}{352} & \multirow[t]{2}{*}{0,002} \\
\hline & Nie mam zdania & & & \\
\hline & Zwolennicy systemu dwupartyjnego & \multirow[t]{2}{*}{1,261} & \multirow[t]{2}{*}{720} & \multirow[t]{2}{*}{ n.i. } \\
\hline & Zwolennicy systemu wielopartyjnego & & & \\
\hline & Zwolennicy systemu dwupartyjnego & \multirow[t]{2}{*}{5,320} & \multirow[t]{2}{*}{524,770} & \multirow[t]{2}{*}{0,000} \\
\hline & Nie mam zdania & & & \\
\hline & Zwolennicy systemu wielopartyjnego & \multirow[t]{2}{*}{4,437} & \multirow[t]{2}{*}{720} & \multirow[t]{2}{*}{0,000} \\
\hline & Nie mam zdania & & & \\
\hline \multirow[t]{12}{*}{ Dyspozycyjny lęk } & Zwolennicy systemu jednopartyjnego & \multirow[t]{2}{*}{1,880} & \multirow[t]{2}{*}{352} & \multirow[t]{2}{*}{ n.i. } \\
\hline & Zwolennicy systemu dwupartyjnego & & & \\
\hline & Zwolennicy systemu jednopartyjnego & \multirow[t]{2}{*}{3,167} & \multirow[t]{2}{*}{540} & \multirow[t]{2}{*}{0,002} \\
\hline & Zwolennicy systemu wielopartyjnego & & & \\
\hline & Zwolennicy systemu jednopartyjnego & \multirow[t]{2}{*}{$-0,255$} & \multirow[t]{2}{*}{352} & \multirow[t]{2}{*}{ n.i. } \\
\hline & Nie mam zdania & & & \\
\hline & Zwolennicy systemu dwupartyjnego & \multirow[t]{2}{*}{1,554} & \multirow[t]{2}{*}{720} & \multirow[t]{2}{*}{ n.i. } \\
\hline & Zwolennicy systemu wielopartyjnego & & & \\
\hline & Zwolennicy systemu dwupartyjnego & \multirow[t]{2}{*}{$-3,072$} & \multirow[t]{2}{*}{532} & 0,002 \\
\hline & Nie mam zdania & & & \\
\hline & Zwolennicy systemu wielopartyjnego & $-5,191$ & 720 & 0,000 \\
\hline & Nie mam zdania & & & \\
\hline
\end{tabular}

Źródło: Opracowanie własne.

\section{Jednomandatowe okręgi wyborcze}

Badanych proszono o wyrażenie swojego stosunku - aprobaty lub dezaprobaty - dla wprowadzenia jednomandatowych okręgów wyborczych w Polsce.

Blisko połowa badanych nie miała określonego zdania w tej kwestii. Wśród pozostałych odpowiedzi dwukrotnie więcej jest zwolenników jednomandatowych okręgów wyborczych, czyli takich, w których obowiązuje ordynacja większościowa, tj. mandat otrzymuje kandydat zdobywający w wyborach najwięcej głosów (Tabela 6). 
Charakterystyki psychologiczne osób o odmiennych preferencjach w zakresie okręgów jednomandatowych

\begin{tabular}{||l|c|c|c|c|c|c|c|c|c||}
\hline & & \multicolumn{2}{|c|}{ Samoocena } & \multicolumn{2}{c|}{$\begin{array}{c}\text { Dyspozycyjny } \\
\text { optymizm }\end{array}$} & \multicolumn{2}{c|}{$\begin{array}{c}\text { Samosku- } \\
\text { teczność }\end{array}$} & \multicolumn{2}{|c|}{$\begin{array}{c}\text { Dyspozycyjny } \\
\text { lęk }\end{array}$} \\
\cline { 3 - 10 } & & $\begin{array}{l}\text { średni } \\
\text { wynik }\end{array}$ & $\%$ & $\begin{array}{c}\text { średni } \\
\text { wynik }\end{array}$ & $\%$ & $\begin{array}{c}\text { średni } \\
\text { wynik }\end{array}$ & $\%$ & $\begin{array}{c}\text { średni } \\
\text { wynik }\end{array}$ & $\%$ \\
\hline $\begin{array}{l}\text { Zwolennicy jednoman- } \\
\text { datowych okręgów wy- } \\
\text { borczych }\end{array}$ & 395 & 38,2 & 76,4 & 21,4 & 71,3 & 29,6 & 74,0 & 48,2 & 60,2 \\
\hline $\begin{array}{l}\text { Przeciwnicy jednoman- } \\
\text { datowych okręgów wy- } \\
\text { borczych }\end{array}$ & 200 & 39,4 & 78,8 & 21,4 & 71,3 & 29,8 & 74,5 & 48,5 & 60,6 \\
\hline Nie mam zdania & 491 & 37,7 & 75,4 & 20,8 & 69,3 & 28,1 & 70,2 & 49,4 & 61,7 \\
\hline
\end{tabular}

Źródło: Opracowanie własne.

Zwolennicy i przeciwnicy jednomandatowych okręgów wyborczych istotnie różnią się jedynie w zakresie samooceny, której niższy poziom prezentują jednostki opowiadające się za wprowadzeniem takiego rozwiązania systemowego.

Zarówno zwolennicy, jak i przeciwnicy mają zdecydowanie wyższy poziom samoskuteczności niż jednostki nie mające własnego zdania w tej kwestii. Dyspozycyjny lęk nie różnicuje istotnie wyróżnionych grup. Mimo braku wyraźnych istotnych różnic warto zwrócić uwagę na powtarzającą się tendencję. Otóż jednostki nieprezentujące określonego stanowiska w kwestii jednomandatowych okręgów wyborczych mają niższy poziom samooceny, dyspozycyjnego optymizmu, własnej skuteczności oraz wyższy dyspozycyjnego lęku niż osoby, które mają konkretne stanowisko.

Tabela 7

Istotność różnic w zakresie analizowanych zmiennych psychologicznych między grupami o różnych preferencjach w zakresie preferencji jednomandatowych okręgów wyborczych

\begin{tabular}{|c|c|c|c|c|}
\hline Zmienna & & $\mathbf{t}$ & $d f$ & p \\
\hline 1 & 2 & 3 & 4 & 5 \\
\hline \multirow[t]{6}{*}{ Samoocena } & Zwolennicy jednomandatowych okręgów wyborczych & \multirow[t]{2}{*}{$-2,424$} & \multirow[t]{2}{*}{586} & \multirow[t]{2}{*}{0,016} \\
\hline & Przeciwnicy jednomandatowych okręgów wyborczych & & & \\
\hline & Zwolennicy jednomandatowych okręgów wyborczych & \multirow[t]{2}{*}{1,189} & \multirow[t]{2}{*}{876} & \multirow[t]{2}{*}{ n.i. } \\
\hline & Nie mam zdania & & & \\
\hline & Przeciwnicy jednomandatowych okręgów wyborczych & \multirow[t]{2}{*}{3,617} & \multirow[t]{2}{*}{684} & \multirow[t]{2}{*}{$\mathbf{0 , 0 0 0}$} \\
\hline & Nie mam zdania & & & \\
\hline
\end{tabular}




\begin{tabular}{|c|c|c|c|c|}
\hline 1 & 2 & 3 & 4 & 5 \\
\hline \multirow{6}{*}{$\begin{array}{l}\text { Dyspozy- } \\
\text { cyjny } \\
\text { optymizm }\end{array}$} & Zwolennicy jednomandatowych okręgów wyborczych & \multirow[t]{2}{*}{$-0,121$} & \multirow[t]{2}{*}{586} & \multirow[t]{2}{*}{ n.i. } \\
\hline & Przeciwnicy jednomandatowych okręgów wyborczych & & & \\
\hline & Zwolennicy jednomandatowych okręgów wyborczych & \multirow[t]{2}{*}{2,268} & \multirow[t]{2}{*}{876} & \multirow[t]{2}{*}{$\mathbf{0 , 0 2 4}$} \\
\hline & Nie mam zdania & & & \\
\hline & Przeciwnicy jednomandatowych okręgów wyborczych & \multirow[t]{2}{*}{1,763} & \multirow[t]{2}{*}{313,666} & \multirow[t]{2}{*}{ n.i. } \\
\hline & Nie mam zdania & & & \\
\hline \multirow{6}{*}{$\begin{array}{l}\text { Samosku- } \\
\text { teczność }\end{array}$} & Zwolennicy jednomandatowych okręgów wyborczych & \multirow[t]{2}{*}{$-0,462$} & \multirow[t]{2}{*}{586} & \multirow[t]{2}{*}{ n.i. } \\
\hline & Przeciwnicy jednomandatowych okręgów wyborczych & & & \\
\hline & Zwolennicy jednomandatowych okręgów wyborczych & \multirow[t]{2}{*}{3,902} & \multirow[t]{2}{*}{858,306} & \multirow[t]{2}{*}{0,000} \\
\hline & Nie mam zdania & & & \\
\hline & Przeciwnicy jednomandatowych okręgów wyborczych & \multirow[t]{2}{*}{3,518} & \multirow[t]{2}{*}{684} & \multirow[t]{2}{*}{0,000} \\
\hline & Nie mam zdania & & & \\
\hline \multirow{6}{*}{$\begin{array}{l}\text { Dyspozy- } \\
\text { cyjny lęk }\end{array}$} & Zwolennicy jednomandatowych okręgów wyborczych & \multirow[t]{2}{*}{$-0,254$} & \multirow[t]{2}{*}{586} & \multirow[t]{2}{*}{ n.i. } \\
\hline & Przeciwnicy jednomandatowych okręgów wyborczych & & & \\
\hline & Zwolennicy jednomandatowych okręgów wyborczych & \multirow[t]{2}{*}{$-1,940$} & \multirow[t]{2}{*}{744,991} & \multirow[t]{2}{*}{ n.i. } \\
\hline & Nie mam zdania & & & \\
\hline & Przeciwnicy jednomandatowych okręgów wyborczych & \multirow[t]{2}{*}{$-1,279$} & \multirow[t]{2}{*}{684} & \multirow[t]{2}{*}{ n.i. } \\
\hline & Nie mam zdania & & & \\
\hline
\end{tabular}

Źródło: Opracowanie własne.

$$
* * *
$$

Przeprowadzone badania uzasadniają wartość analizy uwarunkowań psychologicznych w zakresie formowania się preferencji dotyczących kształtu systemu politycznego w Polsce, co stanowi zachętę do dalszych eksploracji. Poza zarysowanymi wyżej różnicami pomiędzy jednostkami prezentującymi odmienne zdanie na temat struktury systemu rządów, partyjnego oraz okręgów wyborczych odnotować należy kilka konkluzji.

W przypadku poruszonych kwestii dotyczących kształtu systemu politycznego w Polsce jednostki nieposiadające zdecydowanego zdania w zakresie preferowanego systemu rządów, systemu partyjnego oraz jednomandatowych okręgów wyborczych wyróżniały się od jednostek mających określony pogląd najniższym poziomem samooceny, dyspozycyjnego optymizmu, poczucia własnej skuteczności oraz najwyższym poziomem lęku jako cechy. Osoby te prezentują zatem niższy stopień przekonania o własnej wartości. Ponadto są bardziej skłonne do reagowania lękiem w różnych sytuacjach życiowych. Wydają się bardziej podatne na percep- 
cję różnego rodzaju zagrożeń, nawet wówczas, gdy nie istnieją one realnie. Przezwyciężaniu tych stanów nie sprzyjają odnotowane niższe poziomy samoskuteczności i dyspozycyjnego optymizmu, zmiennych, odpowiedzialnych za zaangażowanie i motywację w podjęte działania. Można przypuszczać, że porażka nie stanowi dla tych osób impulsu do rezygnacji, ale podtrzymania wysiłku. Optymiści stosują skuteczniejsze strategie adaptacyjne w konfrontacji z sytuacją trudną. Specyficzna konstelacja tych cech wydaje się być silnym zasobem jednostek aktywnych, świadomych stawianych przed sobą celów, w sytuacjach trudnych reagujących zadaniowo, wytrwałych. W zdecydowanie większym stopniu dyspozycję tę prezentują osoby mające swoje zdanie w analizowanych kwestiach.

Stosunkowo duże odsetki obojętności i braku opinii w poruszonych płaszczyznach (odpowiednio: 30\%, 24,8\%, 45,2\%), mogą również wskazywać na niejasność i niezrozumienie przez znaczną część Polaków zarówno zasad funkcjonowania obecnej ordynacji, jak i możliwych relacji między podmiotami systemu politycznego. Wyniki badań opinii społecznej podtrzymują tezę, że niepokojąco duża część obywateli nie wykazuje zainteresowania oraz zaufania względem polskiej sceny politycznej ${ }^{20}$.

20 Według badań Eurobarometru 2009 Polacy w porównaniu do średniej unijnej są jedną z najbardziej nieufnych wobec instytucji krajowych nacji. Ponad połowa respondentów (54\%) nie ufa wymiarowi sprawiedliwości. Największą nieufność wzbudzająjednak partie polityczne (81\%) i Sejm, którego nie darzy zaufaniem trzy czwarte Polaków. Rządowi nie ufa aż 71\% respondentów, a jedynie co piąty Polak darzy go zaufaniem [Eurobarometr 71, Opinia publiczna w Unii Europejskiej, wiosna 2009]. Autorzy raportu „Psychologiczne profile elektoratów partyjnych” z 2002 zwrócili uwagę, zestawiając wyniki z podobnymi z 1999 oraz 1996 roku, że w tym okresie nieznacznie wzrósł dystans i nieufność względem polityki [Psychologiczne profile elektoratów partyjnych, Komunikat z badań nr BS/95/2002, CBOS, Warszawa, czerwiec 2002]. Badani powszechnie odczuwali brak wpływu na to, co robi rząd, przypisywali większości polityków negatywne motywy działania. Prawie dwie trzecie badanych w $2002 \mathrm{r}$. zadeklarowało, że czuje się obco i nieswojo w obecnym systemie politycznym. Dwie piąte ogółu ankietowanych odrzuca całą sferę polityki jako dziedzinę, w której nie są przestrzegane normy etyczne, podzielając opinię, że ,aby pełnić w naszym kraju jakąś funkcję we władzy, nie można być uczciwym człowiekiem”. Warto zwrócić uwagę na ostatnie wybory do Parlamentu Europejskiego, zainteresowanie którymi było w Polsce na niskim poziomie. Jeszcze w kwietniu, dwa miesiące przed wyborami, prawie połowa uprawnionych do głosowania obywateli twierdziła, że nie tylko nie zna żadnego kandydata na posła do Parlamentu Europejskiego w swoim okręgu wyborczym, ale także nie interesuje się tym, kto będzie kandydował [Wybory do Parlamentu Europejskiego, Komunikat z badań nr BS/63/2009, CBOS, Warszawa, kwiecień 2009]. Miesiąc przed wyborami, w trakcie decydującej fazy kampanii wyborczej, zainteresowanie 
Jednocześnie warto zwrócić uwagę, że w przeprowadzonych badaniach osoby, które nie miały zdania w określonych kwestiach w zakresie kształtu systemu politycznego w Polsce różnią się płcią, wiekiem oraz poziomem wykształcenia. Częściej brak własnego sądu prezentują kobiety. W odniesieniu do wykształcenia można zauważyć, iż wraz ze wzrostem wykształcenia maleje liczba osób niemających zdania w kwestiach kształtu systemu politycznego w Polsce. Natomiast w zakresie przedziałów wiekowych okazuje się, że wielkość grup bez własnego zdania maleje do pewnego wieku, a następnie wzrasta, $\mathrm{z}$ tym że moment wzrostu jest różny w zależności od pytania. W kwestii systemu rządów maleje, by wśród osób powyżej 45 roku życia systematycznie wzrastać. Po 55 roku życia zwiększa się ilość osób bez zdania w zakresie systemu partyjnego. Z kolei dopiero najstarsi obywatele zdecydowanie częściej nie mają zdania w kwestii jednomandatowych okręgów wyborczych (Tabela 8).

Na podstawie przeprowadzonych badań można zauważyć swoistą tendencję. Otóż jednostki preferujące rozwiązania znacząco podkreślające siłę i niezależność w zakresie kształtu systemu politycznego w Polsce prezentują słabszy poziom analizowanych zasobów: niższy poziom samooceny, dyspozycyjnego optymizmu, własnej skuteczności oraz wyższy poziom lęku jako cechy. Osoby o takim układzie dyspozycji częściej są zwolennikami prezydenckiego systemu rządów i systemu jednopartyjne$\mathrm{go}^{21}$. Warto przywołać $\mathrm{w}$ tym kontekście mechanizm walki z poczuciem braku bezpieczeństwa i samotności, zaproponowany przez Ericha Fromma, który może tłumaczyć wskazaną zależność. Autor ten wychodzi z założenia, że ,struktura nowoczesnego społeczeństwa oddziałuje na człowieka w dwojaki sposób: staje się on bardziej niezależny, bardziej samodzielny i krytyczny, a zarazem bardziej wyizolowany, samotny i przerażony"22. Zarówno w sferze gospodarczej, jak i politycznej jednostka staje w obliczu wielkich instytucji, w dużej mierze anonimowych, od-

głosowaniem okazała jedynie jedna trzecia Polaków, uprawnionych do oddania głosu [Wybory do Parlamentu Europejskiego, Komunikat z badań nr BS/82/2009, CBOS, Warszawa, maj 2009]. Polacy mało interesują się mechanizmami działania głównych instytucji unijnych. Mimo tego zaufanie dla Unii Europejskiej w ostatnich latach wyraźnie się umocniło [Postrzeganie instytucji Unijnych, Komunikat z badań nr BS/54/2009, CBOS, Warszawa, kwiecień 2009].

21 Wyraźnej tendencji nie zaobserwowano przy diagnozie preferencji w zakresie okręgów jednomandatowych. Odnotowano jedynie niższy poziom samooceny u jednostek, które opowiadają się za jednomandatowymi okręgami wyborczymi w Polsce.

22 E. Fromm, Ucieczka od wolności, Warszawa 2008, s. 110. 
象?

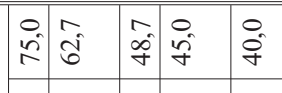

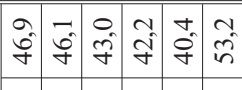

ని

m

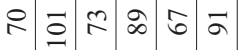

(2)

$\overrightarrow{=} \stackrel{\infty}{2}$

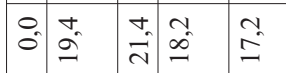

चُ

$\approx \approx$

- m d 요

సิ்ָ

त̂̉

o a a m $\infty$

$a 0_{0} \pi n t_{0}$

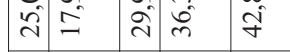

के

은 $\frac{0}{2}$

$-\simeq$ ํํํ

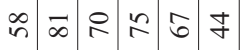

惫

\begin{tabular}{|l|l|}
\hline$a$ & $m$ \\
0 & $\infty$ \\
\hline
\end{tabular}

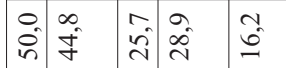

$n=m o g r$

듬

N

ภิ ปิ ปิ

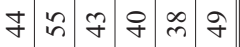

ำ

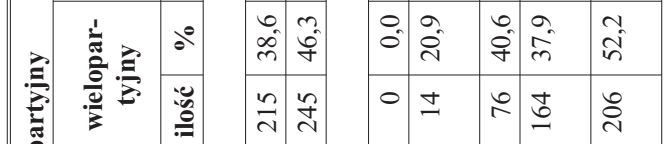

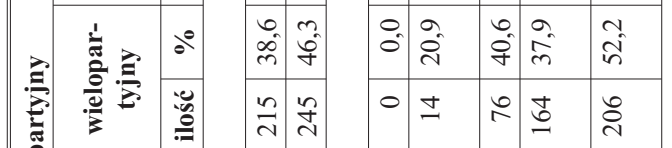

50

$\stackrel{n}{\sim} \stackrel{n}{\sim}$

-

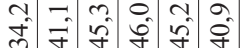

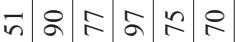

츨

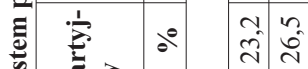

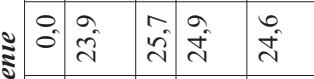

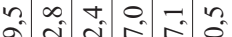

๕ั้

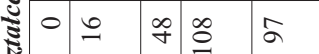

吾言

के

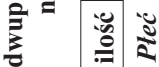

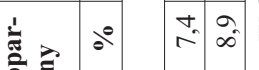

\begin{tabular}{lll|l|l}
0 & + & 0 & $m$ & $=$ \\
0 & 0 & $\infty$ & $\infty$ & 0
\end{tabular}

ฐ

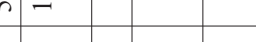

そ)

N $\sim$

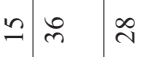

ลิสีสิสิ สิ

サr

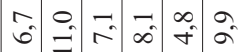

吾 诺

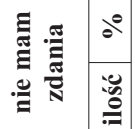

ले बें

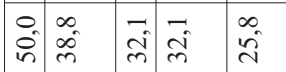

으ㄴㅡㅡㄴ

¿

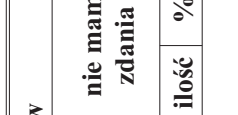

$\stackrel{\infty}{\stackrel{1}{ \pm}}$

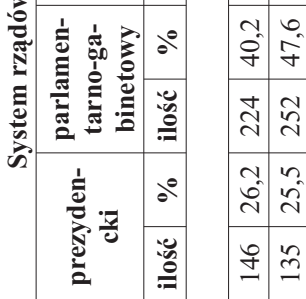

ฟ

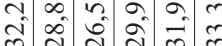

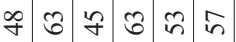

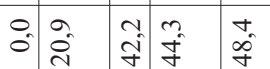

$0-0 . \pi$

भी

○さ হ๐̆

$\infty \begin{array}{llllll}\infty & \infty & \overline{0} & \bar{\sigma} & \ddots\end{array}$

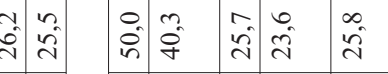

$\Rightarrow n n m m \infty$

章

ข

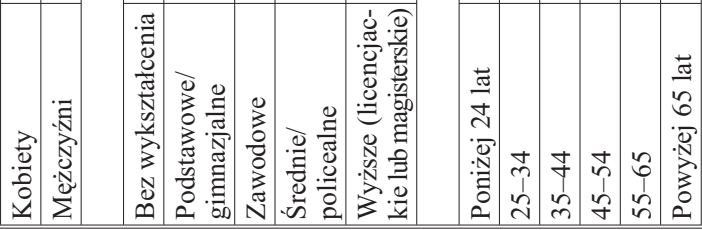

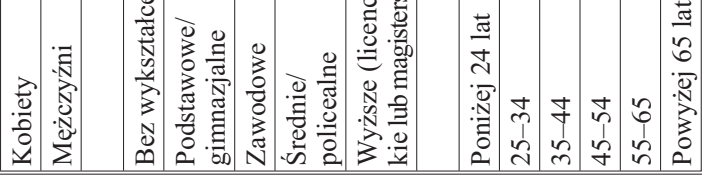

ปิ ขิ สิ के गे

m

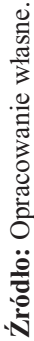


ległych i przytłaczających. Ich założenia programowe są skomplikowane, a rozmaite metody reklamy i propagandy jeszcze bardziej je zaciemniają. Metody te zmierzają do nasilenia poczucia znikomości indywidualnego wyborcy, jednocześnie dając mu złudne poczucie ważności. Wiele czynników strukturalnych, politycznych, ekonomicznych wzmaga poczucie niepewności i braku bezpieczeństwa jednostek. Zaczynają one zatem poszukiwać mechanizmów pozwalających na odnalezienie poczucia siły. Fromm jednego $\mathrm{z}$ mechanizmów niwelowania tych stanów upatruje w podporządkowaniu się wodzowi, próbie współuczestniczenia w większej całości, zewnętrznej wobec jednostki. „Stając się częścią potęgi, uważanej za niewzruszenie silną, wieczną i urzekająca, uczestniczy w jej mocy i chwale [...] uzyskuje nowe poczucie bezpieczeństwa i dumy z uczestniczenia w potędze, przez którą dał się wchłonąć, a zarazem zabezpieczony został przed torturą zwątpienia [...] sens jego życia i tożsamość jego ,ja” są odtąd zdeterminowane przez większą całość, w której owo ,ja” się pogrążyło" ${ }^{23}$. Można przypuszczać, że jednostki o słabszym poziomie zasobów odpowiedzialnych za motywację i zaangażowanie, wyższym poziomie lęku, mniej pozytywnym obrazie własnej osoby częściej doświadczają poczucia braku bezpieczeństwa, a opowiadanie się za systemem prezydenckim oraz jednopartyjnym, może być próbą wyzbycia się poczucia bezsiły. Te systemy właśnie wydają się w największej mierze uzewnętrzniać moc i potęgę, tym samym identyfikacja z nimi może być źródłem poczucia bezpieczeństwa w rozumieniu Fromma. Jest to kruche bezpieczeństwo, jak pisze autor, ale daje wrażenie jedności, mocy i wspólnotowości.

Jednocześnie jednostki o wyższym poziomie analizowanych zasobów wykazują tendencję do wybierania rozwiązań, w których występuje mniejsza koncentracja władzy oraz więcej płaszczyzn współdziałania między podmiotami systemu politycznego - preferują zatem system parlamentarno-gabinetowy oraz system wielopartyjny. Można sądzić, że systemy te dają obywatelom poczucie większego wpływu i współdecydowania o kształcie sceny politycznej w Polsce.

\section{Bibliografia}

Bańka A., Poczucie samoskuteczności. Konstrukcja i struktura czynnikowa Skali Poczucia Samoskuteczności w Karierze Międzynarodowej, Studio PRINT-B, Instytut Rozwoju Karier, Poznań-Warszwa 2005.

23 Ibidem, s. 154. 
Baumeister R. F., Smart L., Boden J. M., Relation of threatened egotism to violence and aggression: The dark side of self-esteem, „Psychological Review” 1996, nr 103.

Blascovich J., Tomaka J., Measures of self-esteem, w: Measures of personality and social psychological attitudes, Vol. 1: Measures of social psychological attitudes, red. J. P. Robinson, P. R. Shaver, L. S. Wrightsman, Academic Press, Nowy Jork 1991.

Dwadzieścia lat przemian ustrojowych w Polsce, „Opinie i Diagnozy”, Centrum Badania Opinii Społecznej, Warszawa 2009.

Eurobarometr 71, Opinia publiczna w Unii Europejskiej, wiosna 2009.

Fromm E., Ucieczka od wolności, Wydawnictwo Czytelnik, Warszawa 2008.

Juczyński, Z., Narzędzia pomiaru w promocji i psychologii zdrowia, Pracownia Testów Psychologicznych Polskiego Towarzystwa Psychologicznego, Warszawa 2001.

Leksykon politologii, red. R. Herbut, A. Antoszewski, Atla 2, Wrocław 1999.

Łaguna M., Lachowicz-Tabaczek K., Dzwonkowska I., Skala Samooceny SES Morrisa Rosenberga - polska adaptacja metody, „Psychologia Społeczna” 2007, t. 2, nr 2(4).

Measures of personality and social psychological attitudes, Vol. 1: Measures of social psychological attitudes, red. J. P. Robinson, P. R. Shaver, L. S. Wrightsman, Academic Press, Nowy Jork 1991.

Modern political parties, red. S. Neumann, Chicago 1958.

Podziat kompetencji między Prezydentem a Premierem, Komunikat z badań nr BS/154/2008, Centrum Badania Opinii Społecznej, Warszawa, kwiecień 2008.

Polacy o proponowanych zmianach $w$ systemie politycznym, Komunikat z badań nr BS/56/2008, Centrum Badania Opinii Społecznej, Warszawa, kwiecień 2008.

Postrzeganie instytucji Unijnych, Komunikat z badań nr BS/54/2009, Centrum Badania Opinii Społecznej, Warszawa, kwiecień 2009.

Prażmowska B., Puto G., Kowal E., Gierat B., Niespetnione macierzyństwo, $\mathrm{http}: / /$ www.termedia.pl/magazine.php?magazine_id=5\&article_id=13877\&magazine_subpage $=$ FULL_TEXT.

Psychologiczne profile elektoratów partyjnych, Komunikat z badań nr BS/95/2002, Centrum Badania Opinii Społecznej, Warszawa, czerwiec 2002.

Scheier M. F., Carver C. S., Bridges M. W., Distinguishing optimism from neuroticism (and trait anxiety, self-mastery, and self-esteem): A reevaluation of the Life Orientation Test, ,Journal of Personality and Social Psychology” 1994, nr 67.

Scheier M. F., Carver C. S., Optimism, coping, and health: assessment and implications of generalized outcome expectancies, „Health Psychology” 1985, nr 4. 
Seligman M., Optymizmu można się nauczyć, Media Rodzina, Poznań 1995.

Sobolewska-Myślik K., Partie i systemy partyjne na świecie, Wydawnictwo Naukowe PWN, Warszawa 2004.

Sosnowski T., Wrześniewski K., Polska adaptacja inwentarza STAI do badania stanu i cechy lęku, „Przegląd Psychologiczny” 1983, nr 26(2).

Turska-Kawa A., Psychologiczne portrety elektoratów w wyborach do Parlamentu Europejskiego w 2009 roku, w: Wybory do Parlamentu Europejskiego w Polsce 2009, red. R. Glajcar, W. Wojtasik, Wydawnictwo REMAR, Katowice 2010.

Wybory do Parlamentu Europejskiego, Komunikat z badań nr BS/63/2009, Centrum Badania Opinii Społecznej, Warszawa, kwiecień 2009.

Wybory do Parlamentu Europejskiego, Komunikat z badań nr BS/82/2009, Centrum Badania Opinii Społecznej, Warszawa, maj 2009.

Wybory do Parlamentu Europejskiego w Polsce 2009, red. R. Glajcar, W. Wojtasik, Wydawnictwo REMAR, Katowice 2010.

\section{Summary}

The paper looks at the issue of the psychological conditioning of the preferences concerning the shape of governance system and the system of political parties in Poland in the light of empirical research $(\mathrm{N}=1086)$, carried out in 2009. The analysis takes into account the variables of self-assessment, dispositional optimism, self-efficacy and dispositional fear. These variables, accounting for the cognitive functioning of individuals, the level of their involvement and motivation, have turned out to be significant when differentiating individuals' preferences concerning political systems. 
